УДК 338.1

DOI: 10.25140/2411-5215-2021-1(25)-82-90

Тетяна Гоголь, Владислава Пономаренко

\title{
ВПЛИВ БУХГАЛТЕРСЬКОГО ОБЛІКУ Й ОПОДАТКУВАННЯ НА ЕКОНОМІКУ УКРАЇНИ ТА ОБ'ЄДНАНИХ АРАБСЫКИХ ЕМІРАТІВ
}

Tatyana Gogol, Vladyslava Ponomarenko

\section{THE IMPACT OF ACCOUNTING AND TAXATION ON THE ECONOMY OF UKRAINE AND THE UNITED ARAB EMIRATES}

\begin{abstract}
У статті визначено місие, яке посідає Україна та Об'єднані Арабські Емірати у світовій економіиі у 2019 роиі відповідно до класифікації країн за методикою Світового банку, проаналізовано основні показники економічного розвитку за 2019 рік, здійснено аналіз структури ВВП в ОАЕ та в Украйні. Також побудовано графіки річного ВВП на душу населення в досліджуваних країнах протягом 2005-2019 рр. Спираючись на законодавчі документи досліджуваних країн, встановлено наявні стандарти у сфері ведення бухгалтерського обліку та складанні фінансової звітності й необхідність їх застосування для різних суб'єктів господарської діяльності. При иьому визначено головні органи, шо регулюють питання, пов'язані з бухобліком, та розкрито їхню функиіональну спрямованість. Розглянуто механізм податкової системи як України, так і Об'єднаних Арабських Еміратів, і відповідну нормативно-правову базу, яка регламентує оподаткування. Визначено вплив бухгалтерського обліку й оподаткування на економіку аналізованих держав.

Ключові слова: економіка; ВВП; бухгалтерський облік; складання фінансової звітності; МСФЗ; податкова система; оподаткування; податки; Украӥна; OAE.

Рис.: 2. Табл.: 3. Бібл.: 18.

The article identifies the place of Ukraine and the United Arab Emirates in the world economy in 2019 according to the classification of countries according to the World Bank, analyzes the main indicators of economic development in 2019, analyzes the structure of GDP in the UAE and Ukraine. Also, graphs of annual GDP per capita in the studied countries during 2005-2019 were constructed. Based on the legislative documents of these countries, the existing standards in the field of accounting and financial reporting and the need for their application to various business entities. At the same time, the main bodies regulating issues related to accounting have been identified and their functional orientation has been revealed. The mechanism of the tax system of both Ukraine and the United Arab Emirates, as well as the relevant legal framework governing taxation are considered. The influence of accounting and taxation on the economy of the analyzed states is determined.

Keywords: economy; GDP; accounting; preparation of financial statements; IFRS; the tax system; taxation; taxes; Ukraine; UAE.

Fig.: 2. Table: 3. References: 18.

JEL Classification: P52, O40, M41, E62
\end{abstract}

Постановка проблеми. Прозоре відображення господарських операцій у бухгалтерському обліку є фундаментальною основою ефективного ведення бізнесу в кожній країні та, безперечно, передумовою розвитку як відповідної галузі, так і самої економіки загалом. Стала законодавча база також відіграє не останню роль у процесі функціонування і підприємств, і держави. Однак змінюється світ, пришвидшується процес глобалізації, удосконалюються виробничі потужності, відбувається оцифрування бізнесу, люди по-новому сприймають явища і процеси, які були звичними для них раніше. Усе це дає поштовх для покращення життя, підвищення економічного розвитку країн i, звичайно, модернізації нормативно-правової бази. До того ж податкова система формує надходження до бюджету, і тим самим забезпечує не лише виконання державою їі функцій, але й дає можливість побачити перспективи сталого розвитку для країни. Ведення бухгалтерського обліку, складання фінансової звітності, законодавчі норми, властиві механізми оподаткування викладають шлях до процвітання держави, хоча їхній вплив $є$ неоднозначним. Саме тому постає питання дослідження цих компонентів та їхнього впливу на економіку країн із різним рівнем економічного розвитку.

Аналіз останніх досліджень і публікацій. Питання щодо рівня економічного розвитку, аспектів бухгалтерського обліку й оподаткування України та Об'єднаних Арабських Еміратів вивчали такі науковці, як М. Шигун, П. Гайдуцький, В. Жук, Г. Лещук, I. Тернова, I. Мудрієвська, Г. Яценко, М. Скрипниченко, А. Томашевська, Т. Смиковчук, I. Дулі, Р. Колісніченко, В. Назарков, К. Полтавченко, М. Кравченко, Р. Покиньчереда, В. Слюсаренко, К. Філіп, О. Трофименко, Е. Трофименко, Н. Логінова, О. Мазіна, 
ФІНАНСОВІ РЕСУРСИ: ПРОБЛЕМИ ФОРМУВАННЯ ТА ВИКОРИСТАННЯ

В. Олійник. Вони здійснили вагомий внесок у науку, розкривши цю проблему у своїх працях, виділивши особливості як бухобліку, фінзвітності, елементів податкової системи, так і нормативно-правового забезпечення, що регламентує ці питання.

Виділення недосліджених частин загальної проблеми. Кожен рік має свої переваги та недоліки стосовно реалізації поставлених завдань (затвердження і виконання планів, наприклад, виконання державного бюджету країни, або ж своєчасне внесення відповідних змін у нормативно-правові акти з метою усунення неузгодженостей у законодавстві), формуючи при цьому загальний вплив на економіку держави. Так, макроекономічні показники розвитку відображають величину змін. Нові закони вносять свої корективи як у ведення господарської діяльності, так і у сферу оподаткування. Багато наукових робіт розкривають ці питання. Однак, щоб краще осягнути досягнутий рівень економічного розвитку загалом, варто звернути увагу одночасно й на місце країни у світовій економіці, i на вивчення основ бухгалтерського обліку, їх нормативно-правовий фундамент, i на механізм оподаткування. Це дозволить проаналізувати як теперішній стан економіки, так і окреслити перспективи майбутнього економічного зростання.

Мета статті. Головною метою цієї роботи $є$ дослідження впливу бухгалтерського обліку й оподаткування на економіку України та Об'єднаних Арабських Еміратів, аналіз основних індикаторів економічного розвитку.

Виклад основного матеріалу. Процвітання кожної країни залежить від іiї економіки, яка, у свою чергу, підносить державу на відповідний рівень розвитку. Так, деякі країни посідають більш провідні позиції у світі, зважаючи на власний досвід, а інші - лише починають свій шлях. 3 метою порівняння і аналізу досягнутого рівня розвитку, систем оподаткування і ведення бухгалтерського обліку у двох зовсім не схожих одна на одну державах, звернемо увагу насамперед на їхнє місце в економічному світовому просторі, потім на мову ведення бізнесу, тобто на сам бухгалтерський облік, а також на елементи податкової системи - податки, чим і окреслимо особливості в зазначених сферах кожної країни.

По-перше, визначимо, які місця посідають аналізовані держави у світовій економіці. Схиляючись до класифікації країн за методикою Світового банку (ВВП на душу населення), бачимо, що Об'єднані Арабські Емірати (ОАЕ) належать до розвинутих держав із великим рівнем доходів і посідають 19-е місце у світі [1]. Натомість Україна належить до країн, що розвиваються, із середнім рівнем доходів на душу населення і посідає 112у позицію [1]. Наведемо основні показники економічного розвитку досліджуваних країн у вигляді табл. 1 та відсотки ВВП, які припадають на провідні галузі, у таблиці 2.

Таблиця 1

Індикатори економічного розвитку ОАЕ та України за 2019 рік

\begin{tabular}{|l|c|c|}
\hline \multicolumn{1}{|c|}{ Індикатор } & ОАЕ & Україна \\
\hline ВВП на душу населення (поточний долар США) & 43103,32 & 3659,03 \\
\hline Приріст ВВП на душу населення (річний, \%) & 0,23 & 3,83 \\
\hline ВВП (поточний долар США, тис.) & 421142267,94 & 153781069,12 \\
\hline Інфляція, дефлятор ВВП (річний, \%) & $-1,90$ & 8,12 \\
\hline
\end{tabular}

Джерело: [1]

Таблиця 2

Структура ВВП в ОАЕ та в Україні за 2019 рік

\begin{tabular}{|c|c|c|}
\hline Показник & OAE & Україна \\
\hline Валовий внутрішній продукт, млн дол. США & 421,1 & 153,8 \\
\hline Сільське господарство, \% від ВВП & 1 & 9 \\
\hline Промисловість, \% від ВВП & 46 & 23 \\
\hline Виробництво, \% від ВВП & 9 & 11 \\
\hline Послуги, додана вартість (\% від ВВП) & 53,1 & 54,4 \\
\hline
\end{tabular}

Джерело: [2]. 
Проаналізувавши наведені дані, можна зробити висновок, що в ОАЕ за 2019 рік ВВП на душу населення становить понад 43 тис. дол. США, в Україні ж - майже у 12 разів менше. На рис. 1 прослідковуються різноманітні коливання ВВП на душу населення протягом 2005-2019 pр., але попри на тенденцію спадання цього показника протягом 2019 року в Об’єднаних Арабських Еміратах, їм притаманний хоч і не значний, але все ж таки додатний приріст ВВП на душу населення (оскільки в розрахунку взято величини реального ВВП), при цьому на 3,6 \% випереджає Україна. Однак звертаємо увагу на дефлятор ВВП, і одразу стає зрозуміло, що цей приріст не що інше, як наслідок інфляції $(8,12$ \%). Також варто звернути увагу й на від’ємне значення цього показника в OAE, що вказує на зниження загального рівня цін в економіці держави. Тепер звернемо увагу на таблицю 2, яка відображає відсоток ВВП у таких галузях, як сільське господарство, промисловість, виробництво та невиробнича сфера. ВВП в ОАЕ майже на половину складається із надходжень від промисловості, в Україні - майже на чверть, але відсоток надходжень від сільського господарства в 9 разів більший, ніж в ОАЕ. До того ж питома вага ВВП з надання послуг (включаючи додану вартість) в обох державах коливається близько $54 \%$.

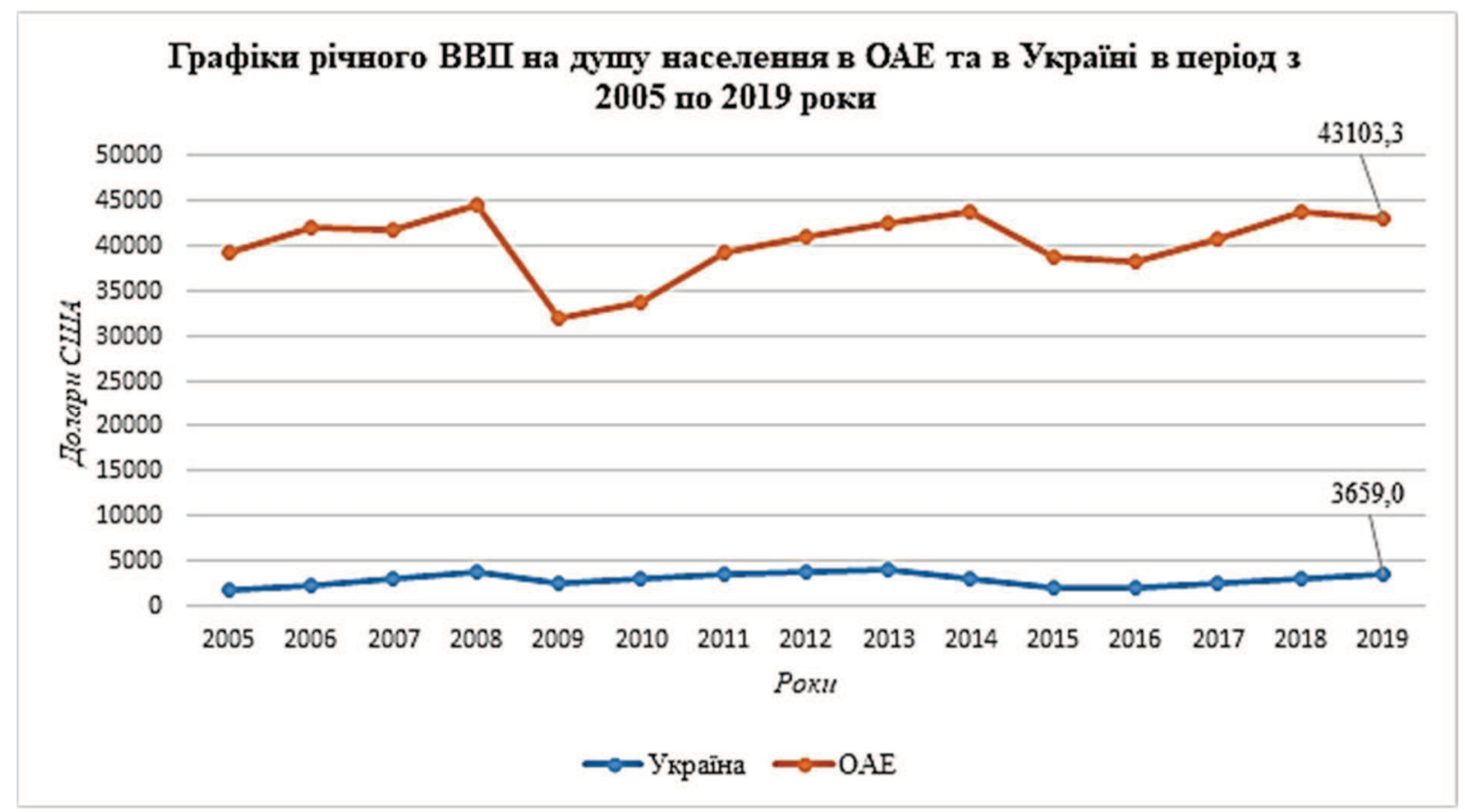

Рис. 1. Графіки річного ВВП на душу населення в ОАЕ та в Україні у період з 2005 по 2019 роки

Джерело: побудовано авторами на основі [1].

Таким чином, зважаючи на таку багатогранність відмінностей у розглянутих індикаторах розвитку, можемо стверджувати, що ОАЕ $є$ розвинутою країною з передовим досвідом, а Україна посідає не останнє місце серед країн, що розвиваються.

По-друге, проаналізуємо організацію бухгалтерського обліку у двох країнах. Відповідно до пп. 18 п. 4 Постанови Кабінету Міністрів України «Про затвердження Положення про Міністерство фінансів України» від 20.08.2014 року № 375 Мінфін є головним органом у системі центральних органів виконавчої влади, що здійснює державне регулювання бухгалтерського обліку, фінансової, бюджетної звітності та аудиту в Україні, розробляє стратегію розвитку національної системи бухгалтерського обліку, а також визначає єдині методологічні засади, обов'язкові для всіх юридичних осіб незалежно від організаційно-правової форми, форми власності та підпорядкування (крім банків), 
ФІНАНСОВІ РЕСУРСИ: ПРОБЛЕМИ ФОРМУВАННЯ ТА ВИКОРИСТАННЯ

здійснює адаптацію законодавства з питань бухгалтерського обліку та аудиту в Україні до законодавства $\mathrm{CC}$, надає індивідуальні роз'яснення з цих питань, якщо вони належать до діяльності заявників [9].

В Україні згідно із Законом «Про бухгалтерський облік та фінансову звітність в Україні» від 16.07.1999 року № 996-XIV (ст. $12^{1}$ ) передбачено застосування міжнародних стандартів [4]. Для деяких підприємств вони є обов’язковими (ч. 2 ст. $12^{1}$ Закону № 996-XIV):

«Підприємства, що становлять суспільний інтерес, публічні акціонерні товариства, суб'єкти господарювання, які здійснюють діяльність у видобувних галузях, а також підприємства, які провадять господарську діяльність за видами, перелік яких визначається Кабінетом Міністрів України, складають фінансову звітність та консолідовану фінансову звітність за міжнародними стандартами» [4].

Крім того, ведення бухгалтерського обліку та складання фінансової звітності регламентується як національними положеннями (стандартами) бухгалтерського обліку (НП(С)БО), так і національними положеннями (стандартами) бухгалтерського обліку в державному секторі та міжнародними стандартами фінансової звітності (МСФ3), введеними в дію відповідно до законодавства, залежно від того, які з наведених стандартів застосовуються підприємством [4].

МСФЗ стали обов'язковими в Україні для всіх компаній, чиї цінні папери циркулюють на публічному ринку, з 1 січня 2012 року [12]. Додатково МСФЗ дозволено було застосовувати з 1 січня 2011 року, а банки станом на цю дату повинні були вже перейти на МСФЗ у складанні річної фінансової звітності; щодо квартальної, то це відбулося дещо пізніше, а саме з першого кварталу 2016 року [12]. Цю вимогу Національний банк України виклав у Постанові № 540 від 18 серпня 2015 року в пп. 2 п. 3:

«Банк складає проміжну фінансову звітність у комплекті скороченої фінансової звітності відповідно до МСБО 34 „Проміжна фінансова звітність”. Комплект скороченої проміжної фінансової звітності має містити інформацію у розрізі всіх заголовків та проміжних підсумків, що були включені в останню річну фінансову звітність» [10].

Варто зазначити, що Стандарт МСФЗ для малих і середніх підприємств (МСП) в Україні офіційно не прийнятий, але згідно з абз. 2 п. 1 розд. IV НП(C)БО 1 його можуть використовувати підприємства, які зобов'язані застосовувати міжнародні стандарти фінансової звітності відповідно до законодавства, а також ті підприємства, які прийняли таке рішення самостійно (за винятком тих, на які не поширюється сфера застосування МСФЗ для МСП), при цьому використовуючи форми звітів, затверджені НП(С)БО 1 [8; 12].

Так розпочався перехід на міжнародні стандарти у різних сферах економіки в Україні. До того ж усі стандарти МСФЗ перекладені українською мовою, а процес перекладу координується Фондом МСФЗ, щоб забезпечити постійний переклад останніх оновлень [12].

В Об'єднаних Арабських Еміратах національним бухгалтерським органом є Асоціація бухгалтерів та аудиторів (англ. The Accountants \& Auditors Association (AAA)), яка зареєстрована як неприбуткова організація, що забезпечує здійснення ключових стратегічних ініціатив для розвитку бухгалтерської та фінансової спеціалізації в країні, а також активно співпрацює з відповідними органами влади, щоб запропонувати стандарти бухгалтерського обліку й аудиту та нові нормативні стандарти для фаху [14]. На жаль, ця організація не затверджує стандарти бухобліку, а лише може їх рекомендувати [13]. Що ж стосується національних стандартів бухгалтерського обліку, то на сьогодні можна констатувати їх відсутність [13].

Головним нормативно-правовим документом у цій сфері виступає Закон „Про комерційні компанії” від 01.07.2015 року № 2 (Закон ОАЕ № 2), який вимагає від усіх компаній застосовувати міжнародні стандарти та практики бухгалтерського обліку під час підготовки своїх рахунків [5; 13]. Так, ОАЕ прийняли стандарти МСФ3 та МСФ3 для МСП. Відповідно до ст. 26 Закону ОАЕ № 2: 
- кожна компанія повинна вести бухгалтерські записи, в яких відображаються здійснені нею операції, щоб у будь-який момент мати можливість розкрити фінансове становище компанії та забезпечити партнерам або акціонерам підтвердження, що іiі рахунки зберігаються належним чином;

- кожна компанія зберігає свої бухгалтерські книги в головному офісі протягом принаймні 5 років з моменту закінчення фінансового року компанії;

- компанія може зберігати електронну копію оригіналу документів, що наявні на зберіганні в ній відповідно до контролю, виданого Міністерським рішенням [5].

Звернемо увагу й на те, що не всі МСФЗ перекладені арабською мовою, нині цей процес триває [13]. Так, Фонд МСФ3 координує публікацію щорічного обмеженого обсягу міжнародних стандартів місцевою мовою [13].

Таким чином, обидві держави практикують застосування міжнародних стандартів фінансової звітності, але в Україні використовують ще й П(С)БО і НП(С)БО в різних секторах економіки відповідно до чинного законодавства, а сам процес переходу офіційно розпочався на чотири роки раніше, ніж в OAE, хоча так і не набув загального характеру. Важливе значення має і наявність МСФЗ, викладених українською мовою, що забезпечує краще розуміння матеріалу як спеціалістами цього фаху, так і бухгалтерами, які не володіють англійською мовою, що, у свою чергу, впливає на швидкість поширення міжнародних стандартів на теренах України.

По-третє, встановимо особливості податкових систем аналізованих країн у розрізі існуючих податків і їхніх ставок. Насамперед згадаємо, що відносини, які виникають у сфері справляння податків і зборів, їх вичерпний перелік та порядок адміністрування, платників, їхні права та обов'язки, компетенцію контролюючих органів, повноваження і обов'язки посадових осіб під час адміністрування податків, а також відповідальність за порушення податкового законодавства регламентує Податковий кодекс України (ПКУ) [3]. Відповідно до ст. 8 ПКУ в Україні встановлюються загальнодержавні і місцеві податки та збори (рис. 2) [3].

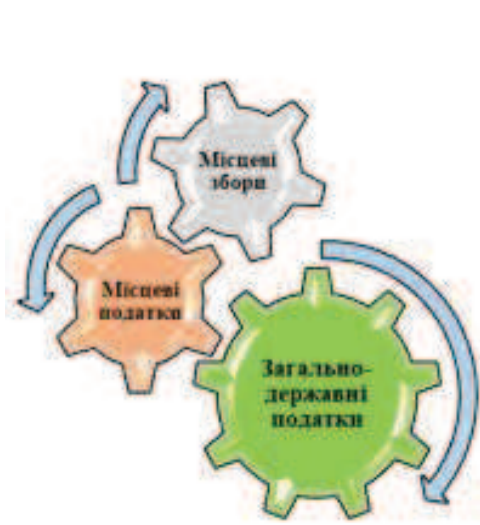

A)

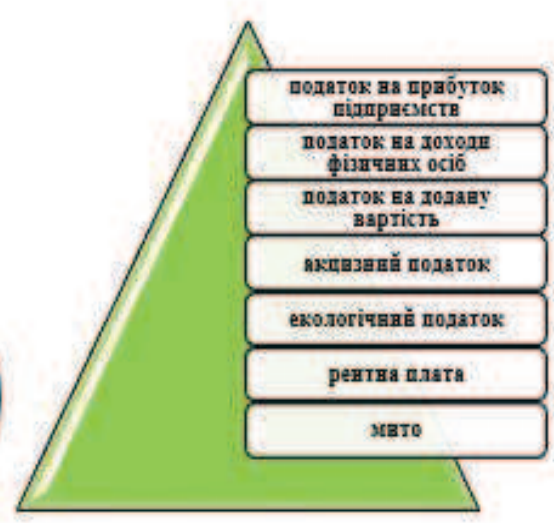

Б)

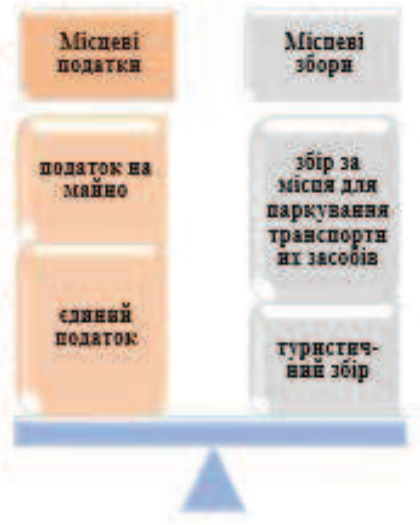

B)

Рис. 2. Податкова система України:

$A$ - класифікаиія податків; $B$ - види загальнодержавних податків; $B$ - види місцевих податків $i$ зборів Джерело: розроблено авторами на основі [3].

Як бачимо, з рис. 2, Б, в Україні затверджено 7 загальнодержавних податків, кожному з яких притаманні свої особливості нарахування та сплати, визначені ПКУ.

В OAЕ, на відміну від української, система оподаткування лише почала своє формування щодо деяких її елементів. Так, Закон «Про акцизний податок» від 01.10.2017 року № 7 (Закон ОАЕ № 7) запровадив стягнення акцизного податку в основному з тютюно- 
ФІНАНСОВІ РЕСУРСИ: ПРОБЛЕМИ ФОРМУВАННЯ ТА ВИКОРИСТАННЯ

вих виробів, газованих та енергетичних напоїв, а також з інших некорисних товарів для населення, які виготовляються або імпортуються на територію ОАЕ [6]. Згідно зі ст. 3 цього Закону ставка податку не повинна перевищувати $200 \%$ ціни; а ст. 11 регламентується включення податку в рекламовану ціну, тобто оголошені ціни акцизних товарів уже включають цей податок (крім випадків, визначених Законом ОАЕ № 7) [6]. До того ж зазначено, що від оподаткування звільняються акцизні товари, які експортуються (ст. 12 Закону ОАЕ № 7) [6].

Не набув чинності й ще один нормативно-правовий документ, а саме Закон «Про ПДВ» від 01.01.2018 року № 8 (Закон ОАЕ № 8), який врегулював питання стосовно нарахування та сплати податку на додану вартість. Відповідно до ст. 3 цього Закону стандартна ставка встановлена в розмірі $5 \%$; а ст. 38 передбачає відображення рекламної ціни вже з урахуванням ПДВ [7]. Статтею 45 Закону ОАЕ № 8 перераховано товари й послуги, які підлягають нульовій ставці, серед них: прямий або непрямий експорт, міжнародний транспорт пасажирів та товарів, постачання або імпорт інвестиційних дорогоцінних металів, постачання сирої нафти та природного газу й інші [7]. Звільняються від сплати податку на додану вартість:

- фінансові послуги, визначені відповідно до чинного законодавства;

- постачання житлових будинків шляхом продажу чи здавання в оренду, крім тих, що мають нульову ставку податку;

- постачання землі;

- постачання місцевого пасажирського транспорту (ст. 46 Закону ОАЕ № 8) [7].

Що стосується реєстрації як платника ПДВ, то згідно 3 п. 1 ст. 13 вона має обов'язковий характер у разі, якщо загальна вартість усіх поставок перевищує або межу обов'язкової реєстрації за попередній 12-місячний період або обов'язковий поріг реєстрації протягом наступних тридцяти днів після іiї здійснення [7]. Крім того, передбачена й добровільна реєстрація відповідно до ст. 17 Закону ОАЕ № 8 [7].

А тепер порівняємо всі дані про податки в Україні та в Об'єднаних Арабських Еміратах за допомогою таблиці 3.

Таблиця 3

Загальнодержавні податки та їх ставки в ОАЕ та в Україні

\begin{tabular}{|c|c|c|}
\hline \multirow[t]{2}{*}{ Податок } & \multicolumn{2}{|c|}{$\begin{array}{c}\text { Нормативна ставка податку } \\
\text { у відсотках від бази оподаткування }\end{array}$} \\
\hline & $\mathrm{OAE}$ & Україна \\
\hline Податок на прибуток підприємств & - & 18 \\
\hline Податок на доходи фізичних осіб & - & 18 \\
\hline Податок на додану вартість & 5 & 20 \\
\hline Акцизний податок & $\begin{array}{l}\text { різні ставки } \\
\text { до } 200 \%\end{array}$ & різні ставки \\
\hline Екологічний податок & - & різні ставки \\
\hline Рентна плата & - & різні ставки \\
\hline Мито & - & різні ставки \\
\hline
\end{tabular}

Джерело: [3; 6; 7; 15-18].

Таким чином, спостерігаємо диспропорцію в кількості податків, і ставка ПДВ в Україні більша в чотири рази. Варто відзначити, що в табл. 3 дані про ставки в ОАЕ $є$ стандартними, тобто відносяться до кожного емірату у складі федерації, які, у свою чергу, також можуть затверджувати як інші місцеві податки та збори, так і відповідні їм ставки оподаткування $[6 ; 7 ; 15]$. Також треба звернути увагу і на наявність вільних економічних зон, де податки стягуються відповідно до спеціальних режимів, а то і взагалі відсутні. 
3 метою уникнення подвійного оподаткування та запобігання податкових ухилень стосовно податків на доходи і капітал між Україною та Об'єднаними Арабськими Еміратами було укладено угоду від 22.01.2003 року, яка «застосовується до податків на доходи і на капітал, що стягуються від імені Договірної Держави або іiі політикоадміністративних підрозділів, або місцевих органів влади, або місцевих урядів, незалежно від способу їх стягнення» (п. 1 ст. 2 цієї угоди) [11].

Так, обгрунтовуючи відмінності, можемо стверджувати, що питання стосовно справляння податків та зборів більш точно прописані в Податковому кодексі України за кожним їх видом, що полегшує пошук потрібної інформації та іiї сприйняття; у законодавчій базі ОАЕ наявні декілька документів, що регламентують оподаткування. На противагу семи українським загальнодержавним податкам у податковій системі ОАЕ існує лише два, які застосовуються до всіх еміратів. Це пояснюється тим, що кожній державі притаманна своя форма правління, а саме: Україна - унітарна парламентсько-президентська республіка, ОАЕ - федерація абсолютних монархій (із семи еміратів) $[17 ; 18]$.

Висновки і пропозиції. Отже, підсумовуючи, можна зробити висновок, що Україна посідає 112-е місце за оцінкою Світового банку у 2019 році за рівнем економічного розвитку із 185 країн світу, натомість Об'єднані Арабські Емірати - на дев'яносто три сходинки вище, що підкреслює передовий досвід їхнього розвитку в економічному світовому просторі. Що стосується величини річного ВВП на душу населення, то в Україні вона становить 3659,03 дол. США і майже в 12 разів $є$ меншою за розмір цього індикатора в ОАЕ. При цьому структурна частка ВВП, яка припадає на сільське господарство, вказує на перевагу аграрного напряму в економіці України, у свою чергу, питома вага ВВП, що належить промисловості ОАЕ, чітко окреслює спрямованість Об'єднаних Арабських Еміратів на індустрію. Незважаючи на відмінності розвитку секторів економіки, обидві країни нарощують ВВП на душу населення, про що свідчить додатний приріст такого показника, і тим самим покращують добробут усіх своїх громадян, забезпечуючи їм світле майбутнє. Спільним для обох держав є застосування МСФЗ у системі бухгалтерських рахунків та складанні фінансової звітності; відмінним - те, що в OAЕ не існує національних стандартів, а відповідний орган, що регулює питання в цій сфері, не має повноважень щодо їх затвердження. До того ж система оподаткування в Україні закріплена Податковим кодексом від 2 грудня 2010 року, а перший елемент податкової системи Об’єднаних Арабських Еміратів - акцизний податок, лише з 1 жовтня 2017 року, що вказує на початок процесу формування загальнодержавних податків у цій країні. Отже, зважаючи на особливості економічного розвитку, відмінності бухгалтерського обліку та оподаткування в аналізованих країнах, можемо стверджувати, що економіка ОАЕ вже процвітає, а уряд і надалі оновлює нормативну базу; Україна ж лише виходить на шлях розквіту соціально-економічного добробуту країни, рухаючись кроками інтеграції та модернізуючи чинне законодавство.

\section{Список використаних джерел}

1. World Development Indicators. URL: https://databank.worldbank.org/reports.aspx?source=worlddevelopment-indicators.

2. World Development Indicators: Structure of output. URL: http://wdi.worldbank.org/table/4.2.

3. Податковий кодекс України : Кодекс України від 02 грудня 2010 р. № 2755-VI. URL: https://zakon.rada.gov.ua/laws/show/2755-17\#Text.

4. Про бухгалтерський облік та фінансову звітність в Україні : Закон України від 16 липня 1999 p. № 996-XIV. URL: https://zakon.rada.gov.ua/laws/show/996-14\#Text.

5. Federal Law No. 2 of 2015 on Commercial Companies (2015, July 1). URL: http://rakez.com/Portals/0/Download/UAE-Rules-and-Regulations/Federal-Law-No-2-of-2015-onCommercial-Companies.pdf. 
ФІНАНСОВІ РЕСУРСИ: ПРОБЛЕМИ ФОРМУВАННЯ ТА ВИКОРИСТАННЯ

6. Federal Law No. 7 of 2017 on Excise Tax (2017, October 1). URL: https://www.mof.gov.ae/ en/lawsAndPolitics/govLaws/Documents/Federal\%20DecreeLaw\%20No.7\%20of\%202017\%20on\%20Excise\%20Tax.pdf.

7. Federal Law No. 8 of 2017 on VAT (2018, January 1). URL: https://www.mof.gov.ae/ en/lawsAndPolitics/govLaws/Documents/VAT\%20Decree-Law\%20No.\%20(8)\%20of\%202017\%20$\% 20$ English.pdf.

8. Національне положення (стандарт) бухгалтерського обліку 1 «Загальні вимоги до фінансової звітності» : затв. наказом Міністерства фінансів України від 07 лютого 2013 р. № 73. URL: https://zakon.rada.gov.ua/laws/show/z0336-13\#Text.

9. Про затвердження Положення про Міністерство фінансів України : Постанова Кабінету Міністрів України від 20 серпня 2014 р. № 375. URL: https://zakon.rada.gov.ua/laws/show/3752014-\%D0\%BF\#Text.

10. Про внесення змін до постанови Правління Національного банку України від 24 жовтня 2011 року № 373 : Постанова Правління Національного банку України від 18 серпня 2015 р. № 540. URL: https://zakon.rada.gov.ua/laws/show/v0540500-15\#Text.

11. Про уникнення подвійного оподаткування та попередження податкових ухилень стосовно податків на доходи і капітал : Угода між Урядом України і Урядом Об'єднаних Арабських Еміратів від 22 січня 2003 p. URL: https://zakon.rada.gov.ua/laws/show/784_003\#Text.

12. IFRS application around the world. Jurisdictional profile: Ukraine. URL: https://www.ifrs.org/-/media/feature/around-the-world/jurisdiction-profiles/ukraine-ifrs-profile.pdf.

13. IFRS application around the world. Jurisdictional profile: United Arab Emirates. URL: https://www.ifrs.org/-/media/feature/around-the-world/jurisdiction-profiles/united-arab-emirates-ifrsprofile.pdf.

14. About Accountants \& Auditors Association. URL: http://aaa4uae.ae/?page id $=474$.

15. Вихід на ринок Об'єднаних Арабських Еміратів. URL: https://uae.mfa.gov.ua/ spivrobitnictvo/vihid-na-rinok-obyednanih-arabskih-emirativ.

16. World Bank Group (2019). Paying Taxes 2019. URL: https://www.doingbusiness.org/ content/dam/doingBusiness/media/Special-Reports/PwC---Paying-Taxes-2019---Smaller19112018.pdf.

17. Economy Profile Ukraine. Doing Business 2020 (2018). URL: https://www.doingbusiness.org/content/dam/doingBusiness/country/u/ukraine/UKR.pdf.

18. Economy Profile United Arab Emirates. Doing Business 2020 (2018). URL: https://www.doingbusiness.org/content/dam/doingBusiness/country/u/united-arab-emirates/ARE.pdf.

\section{References}

1. World Development Indicators. https://databank.worldbank.org/reports.aspx? source=worlddevelopment-indicators.

2. World Development Indicators: Structure of output. http://wdi.worldbank.org/table/4.2.

3. Podatkovyi kodeks Ukrainy [Tax Code of Ukraine], Code of Ukraine № 2755-VI (of December 2, 2010]. https://zakon.rada.gov.ua/laws/show/2755-17\#Text.

4. Pro bukhhalterskyi oblik ta finansovu zvitnist v Ukraini [On Accounting and Financial Reporting in Ukraine], Law of Ukraine № 996-XIV (of July 16, 1999). https://zakon.rada.gov.ua/ laws/show/996-14\#Text [in Ukrainian].

5. Federal Law No. 2 of 2015 on Commercial Companies (2015, July 1). http://rakez.com/Portals/ 0/Download/UAE-Rules-and-Regulations/Federal-Law-No-2-of-2015-on-Commercial-

Companies.pdf.

6. Federal Law No. 7 of 2017 on Excise Tax (2017, October 1). https://www.mof.gov.ae/en/ lawsAndPolitics/govLaws/Documents/Federal\%20Decree-

Law\%20No.7\%20of\%202017\%20on\%20Excise\%20Tax.pdf.

7. Federal Law No. 8 of 2017 on VAT (2018, January 1). https://www.mof.gov.ae/en/ lawsAndPolitics/govLaws/Documents/VAT\%20Decree-Law\%20No.\%20(8)\%20of\%202017\%20$\% 20$ English.pdf. 
8. Natsionalne polozhennia (standart) bukhhalterskoho obliku 1 «Zahalni vymohy do finansovoi zvitnosti» [National Regulation (Standard) of Accounting 1 "General requirements for financial reporting"], Standard № 73 (on February 7, 2013). https://zakon.rada.gov.ua/laws/show/z0336-13\#Text.

9. Pro zatverdzhennia Polozhennia pro Ministerstvo finansiv Ukrainy [On approval of the Regulation on the Ministry of Finance of Ukraine], Resolution of the Cabinet of Ministers of Ukraine № 375 (of August 20, 2014). https://zakon.rada.gov.ua/laws/show/375-2014-\%D0\%BF\#Text.

10. Pro vnesennia zmin do postanovy Pravlinnia Natsionalnoho banku Ukrainy vid 24 zhovtnia 2011 roku № 373 [On Amendments to the Resolution of the Board of the National Bank of Ukraine of October 24, 2011 № 373], Resolution of the Board of the National Bank of Ukraine № 540 (of August 18, 2015). https://zakon.rada.gov.ua/laws/show/v0540500-15\#Text.

11. Pro unyknennia podviinoho opodatkuvannia ta poperedzhennia podatkovykh ukhylen stosovno podatkiv na dokhody i kapital [On the avoidance of double taxation and the prevention of fiscal evasion with respect to taxes on income and on capital], Agreement between the Government of Ukraine and the Government of the United Arab Emirates (of January 22, 2003). https://zakon.rada.gov.ua/laws/show/784_003\#Text.

12. IFRS application around the world. Jurisdictional profile: Ukraine. https://www.ifrs.org//media/feature/around-the-world/jurisdiction-profiles/ukraine-ifrs-profile.pdf.

13. IFRS application around the world. Jurisdictional profile: United Arab Emirates. https://www.ifrs.org/-/media/feature/around-the-world/jurisdiction-profiles/united-arab-emirates-ifrsprofile.pdf.

14. About Accountants \& Auditors Association. http://aaa4uae.ae/?page_id=474.

15. Vykhid na rynok Obiednanykh Arabskykh Emirativ [Entering the market of the United Arab Emirates]. https://uae.mfa.gov.ua/spivrobitnictvo/vihid-na-rinok-obyednanih-arabskih-emirativ.

16. World Bank Group (2019). Paying Taxes 2019. https://www.doingbusiness.org/content/ dam/doingBusiness/media/Special-Reports/PwC---Paying-Taxes-2019---Smaller-19112018.pdf.

17. Economy Profile Ukraine. Doing Business 2020 (2018). https://www.doingbusiness.org/ content/dam/doingBusiness/country/u/ukraine/UKR.pdf.

18. Economy Profile United Arab Emirates. Doing Business 2020 (2018). https://www.doingbusiness.org/content/dam/doingBusiness/country/u/united-arab-emirates/ARE.pdf.

Гоголь Тетяна Анатоліївна - доктор економічних наук, професор, професор кафедри бухгалтерського об-

ліку, оподаткування та аудиту, Національний університет «Чернігівська політехніка» (вул. Шевченка, 95, м. Чернігів, 14035, Україна).

Gogol Tetyana - Doctor of Economics, Professor, Professor of the Department of Accounting, Taxation and Audit, Chernihiv Polytechnic National University (95 Shevchenko Str., 14035 Chernihiv, Ukraine).

E-mail: tatyanagogoll@gmail.com

ORCID: https://orcid.org/0000-0002-7830-2936

Пономаренко Владислава Сергіївна - студентка, Національний університет «Чернігівська політехніка» (вул. Шевченка, 95, м. Чернігів, 14035, Україна).

Ponomarenko Vladyslava - Student, Chernihiv Polytechnic National University (95 Shevchenko Str., 14035 Chernihiv, Ukraine).

E-mail: potestatemgloria@gmail.com

ORCID: https://orcid.org/0000-0001-7777-6155

Гоголь Т., Пономаренко В. Вплив бухгалтерського обліку й оподаткування на економіку України та Об'єднаних Арабських Еміратів. Проблеми і перспективи економіки та управління. 2021. № 1(25). С. 82-90. 